\title{
Standard fees for legal aid: An empirical analysis of incentives and contracts*
}

\author{
June 15, 2006
}

\begin{abstract}
This paper aims to provide evidence on a fundamental assumption of contract theory: that agents respond to financial incentives. It uses data from before the introduction of standard fees for some legal aid lawyers in England and Wales in 1993. For some inputs, these substituted a fixed price contract for retrospective fee-for-service remuneration, while retaining fee-for-service for travel and waiting time supplied by lawyers. We look at the effects of these new contracts on case-level inputs and also examine the extent of substitution across inputs in response to the two means of payment on offer. Our results suggest that lawyers responded in ways that are consistent with theory: (i) high-powered incentives for cost-reduction lowered inputs that may have been difficult to monitor, and (ii) substitution across inputs took place in line with a simple view of multitask agency. Our results have implications for economic theory as well as for legal aid expenditure control, and current policies on personal injury litigation.
\end{abstract}

Keywords: Incentives, contracts, legal aid

JEL classification: K4, J2

\footnotetext{
${ }^{*}$ We are grateful to the Editor and two anonymous referees for comments. Earlier versions of this paper were presented at the Annual Conference of the American Law and Economics Association, Yale, May 1999, and the Annual Conference of the European Association of Law and Economics, Utrecht, September 1998. We thank Ian Crawford, Mary Olson and Richard Posner for comments. We are grateful to the Legal Services Commission for providing the data used in this paper, and to the Department of Constitutional Affairs for funding some of the work. Opinions and errors are our own.
} 


\section{Introduction}

A fundamental assumption of contract theory is that agents respond to financial incentives provided in the contracts offered by their principals. Two commonly observed forms of contract are retrospective payments for inputs supplied (often known as 'piece rates') and payments on the basis of prospectively set fees. Laffont and Tirole (1993) examine the 'high-powered' incentives associated with moving to prospective payment: by making agents residual claimants to any surplus on the contract, these can prevent artificial inflation of (unobservable) inputs. Holmström and Milgrom (1991) provide additional insights by noting that many jobs involve multiple tasks (see also Baker, 1992). Such "multitasking" can lead workers to substitute between inputs depending on whether these can be verified and how they are remunerated.

In this paper, we seek to test for these effects, by examining the response of lawyers in England and Wales to changes in the way they have been paid for some legally aided criminal cases. Because these changes spanned a period which saw retrospective fee-for-service payment replaced by prospectively fixed fees, our data provide a natural experiment for considering the effects of this change. Moreover, because not all inputs were covered by the contractual change observed in this period, we have a unique opportunity to explore the way in which input mix may respond to financial incentives. Thus, our results are of interest from both theoretical and policy perspectives.

The natural experiment in question took place in 1993, as a response to the substantial year-on-year increases in government expenditure on legal aid which had occurred over the previous ten years (Gray, 1994). A driving economic idea behind the legal reforms proposed in this period was that legal aid generated a set of principal-agent relationships akin to those in 
health care markets (with third party payers potentially unable to monitor input choices). As such, it was suggested that evidence about the effects of financial incentives, particularly with respect to whether suppliers could artificially induce demand, could usefully be imported from such experiences (see Bevan 1996, 1998). In particular, attention was drawn to the introduction of Prospective Payment Systems (PPS) in the US, where fixing fees in advance was intended to remove incentives for over-supply, and the effects of such contracts on expenditure and drug choice have been extensively examined (see below).

We study the introduction of prospectively fixed fees in criminal cases in Magistrates' Courts in 1993. In cases where lawyers had previously presented the Legal Aid Board (the legal aid 'regulator' until 2000') with an itemised bill for payment based on piece rates at the end of the case, a system of standard fees was introduced, which provided them with a prospectively fixed payment for a large part of their work on the case (while retaining piece rates for a selection of inputs). The move to standard fees clearly implies a shift from retrospective fee-for-service payment to high-powered prospective payment. The changes also emphasise the multitask nature of the services provided by lawyers in legal cases. Thus, for example, on any given case, lawyers must supply preparation time, travel and waiting time, and perhaps perform advocacy. The fact that different tasks are remunerated in different ways under the standard fees we examine is, potentially, consistent with multitask theory.

Bearing these points in mind, if lawyers respond to financial incentives the shift to standard fees can be predicted to have had implications for the

\footnotetext{
${ }^{1}$ The Legal Aid Board was replaced by the Legal Services Commission in 2000. Because our data pre-date this change we refer to the Legal Aid Board in what follows
} 
number and types of inputs they supplied on similar cases. Whilst earlier work (Gray, Fenn and Rickman, 1996a) describes and simulates some of these effects, empirical tests have been lacking to date. ${ }^{2}$ In this paper we redress this position, using data on the legal aid bills submitted by lawyers in Magistrates' Court criminal cases over the period 1988-1994. Because our data consists of information on both standard and non-standard fee bills, including the range of inputs to which they apply, we are able to examine retrospective fee-for-service versus fixed price contracts, and the extent of multitask flexibility. ${ }^{3}$

Of course, such work has important policy implications as well as bearing on the contractual issues raised above. Within legal aid, the control of expenditure remains a central policy issue (see Cape and Moorhead, 2005). Further, prospectively fixed fees have been proposed, and implemented, in a number of areas of the legal system since standard fees were introduced for criminal legal aid. Most recently, such fees have been introduced for the vast majority of road traffic claims in England and Wales (DCA, 2003) and similar schemes are under discussion for employers' liability and public liability claims; thus, a significant fraction of tort claims could soon be run under prospectively set fees in England and Wales. ${ }^{4}$ Clearly, the lawyers' responses to standard fees may have implications for the services that will be supplied

\footnotetext{
${ }^{2}$ Some evidence exists to suggest that solicitors responded to the changed financial incentives they faced under standard fees; however, this does not relate directly to the inputs they supplied. In particular, it has been argued that standard fees led solicitors to "redefine" a case so that more than one fee could be charged for work that previously appeared on the same bill: a phenomenon known as case-splitting. The Legal Aid Board (1994) alludes to such behaviour and subsequent research from the Legal Aid Area Office in Newcastle (1994-95) is also consistent with this.

${ }^{3}$ Because our data do not contain information on different types of simultaneously available contract, we do not address the optimality of the contract on offer. See, for example, Gibbons and Murphy (1992) and Slade (1996).

${ }^{4}$ Other examples of fixed fee proposals include those in Woolf (1996) and the system of standard fees introduced for Scottish criminal claims in 1999.
} 
under these current reforms.

A variety of studies seek to test the effects of contracts in different organisational setings and it is important to relate our work to these. As Prendergast (1999) notes, Lazear (1996) and Paarsch and Shearer (1996) provide relatively rare analyses of the empirical effects of piece rate contracts in standard employment contracts. By contrast, professional services have provided more opportunities for empirical research. This is particularly true of health care, where US Medicare has provided fertile territory for such research - see the excellent survey in Bickerdyke et al. (2002). ${ }^{5}$ An early study by Rice (1983) uses changes in reimbursement rates to look for evidence of demand inducement, as do later studies by Krasnik et al. (1990) and Yip (1998). By and large, changes in fees have not been the basis for work on demand inducement, however (see Folland, Goodman and Stano, 2001, p. 171). Instead, research has largely focused on the (essentially fixed price) Prospective Payment Systems (PPS) introduced in 1983, in response to worries about the incentives for physicians to inflate demand under third party funded retrospective fee-for-service schemes - a structure that resembled legal aid at that time. The prospective payments were based on Diagnostic-Related Groups (DRGs), which categorise each patient care episode by expected level of resource use and cost, and covered hospital charges, but physicians were still reimbursed on a per-item basis. Contributions by Phelps (1986), Pauly (1994a, b) and Labelle et al. (1994 a, b) and others have developed (and examined empirically) a conceptual framework for supplier-induced demand in US health care. Much subsequent work (for example, Gay and Kronenfeld, 1990; McClennan, 1997; Dismuke and Sena, 1999, for Portugal; Gilman,

\footnotetext{
${ }^{5}$ We have already noted that the well-documented parallels between principal-agent problems in legal services and health care (see Arrow, 1963) and the impact of evidence from health care on legal aid policy in the England and Wales.
} 
2000; Kroneman and Nagy, 2001, for Hungary) has looked at the subsequent effects of PPS by DRG, but typically not at the level of individual physician income. Finally, Gray, Rickman and Fenn (1999) provide an interesting parallel with health care work by looking at whether payment schemes generate supplier-induced demand by law firms.

Our paper differs from the above work in several key respects. First, unlike PPS by DRG, standard fees affect lawyers' fees directly so the links to behaviour are clearer. ${ }^{6}$ Second, our data are particularly unusual in containing changes in fees over time and within case. As such, they allow us to examine the effects of prospective payment and the extent of multitaskstyle substitution between inputs, something which remains relatively unexplored. ${ }^{7}$ Finally, our data are unusual in providing a UK perspective on these issues and, as we have noted, they relate to important debates within UK legal systems at present. ${ }^{8}$

The paper is structured as follows. The next section describes the feefor-service and standard fee arrangements operating in criminal Magistrates' Courts before and after 1993. Section 3 then describes the predictions we are able to test arising from the switch between these arrangements in 1993. In Sections 4 and 5 we present our data and results, before Section 6 concludes the paper.

\footnotetext{
${ }^{6}$ Similarly, as our data relate specifically to inputs, as opposed to the outcomes of behaviour, this also provides a close link to contract theory.

${ }^{7}$ Olson (1996) and Slade (1996), both provide empirical results on multitasking. Schramm and Gabel, 1988, describe PPS-related shifts cross different kinds of work (not within a job) induced by DRGs, while Krasnik et al. (1990) provide limited evidence on substitution for retrospective fee-for-service graduated across different health care interventions.

${ }^{8}$ Indeed, having noted links from health policy research to legal aid policy, it is interesting that current English health policy is also moving towards fixed price reimbursement for hospitals and other providers, based on a standard national tariff applied to services delivered. Thus, our work may have still wider policy relevance.
} 


\section{Standard fees in Magistrates' Courts}

The Legal Aid in Criminal and Care Proceedings (Costs) Regulations 1989 provided for a system of standard fees in the Magistrates' Courts a year after they had been introduced in the Crown Court. However, strong dissent from lawyers (both solicitors and barristers) delayed their becoming operational for a further four years (see Zander, 1993). Tables 1 and 2 present the information necessary for explaining the operation of standard fees at the time they were introduced. The Tables relate to the fees paid in 1993/4 for non-franchised legal aid work outside London. ${ }^{9}$

\section{***Tables 1 and 2 here $* * * *$}

As can be seen from Table 1, standard fees apply in three categories of cases. Broadly speaking, these are guilty pleas and other uncontested matters (Category 1), contested trials (Category 2) and committal proceedings (Category 3). Given the case's category, its core cost can be calculated. This was done in 1993/4 by applying the rates in Table 2 to the amounts of inputs reported by the solicitor as having been provided on the case.

The inputs forming the core cost are preparation, routine letters and telephone calls, advocacy and attendance on client(s) and counsel at court. ${ }^{10}$ If the core cost fell below the lower limit in Table 1, the solicitor received the lower standard fee to cover this work (e.g. £140 in Category 1 cases). If the core cost lay between the lower and higher limits in Table 1, the higher standard fee was paid by the Legal Aid Board. Finally, if the solicitor could

\footnotetext{
${ }^{9}$ Our discussion of the operation of standard fees ignores a number of complicating factors which are not important to what follows. The interested reader is directed to Edwards (1993).

${ }^{10}$ Note that "attendance" relates to timetabled court time as opposed to untimetabled waiting time (the latter features in non-core costs, below). This is important for Section 5 , where attendance is treated (correctly) as exogenous to the solicitor.
} 
demonstrate core cost in excess of the higher limit, the work done was remunerated at the itemised rates in Table 2 . Hence the fee was graduated, with the allowable level depending on the solicitor's report, audited by the Legal Aid Board, of the work supplied to the case. This basis for remunerating criminal legal aid cases remains essentially the same to date, with the rates and limits uprated periodically by the successor to the Legal Aid Board, the Legal Services Commission.

It will be clear from this description that the components of the core cost do not cover all of the solicitor's work. In particular, travel and waiting and out-of-pocket disbursements are each reimbursed at itemised rates (in the case of the former, the 1993/4 rate is in Table 2), as was true of all inputs prior to 1993. Further, the solicitor may be able to claim percentage enhancements to the itemised rates, based on demonstrating the exceptional competence and dispatch with which the work was done or the exceptional circumstances of the case. If either is deemed proven, standard fees do not apply.

\section{Standard fees and economic theory}

A solicitor's input decision on a given case can be thought of as labour supply decision, with the movement towards standard fees altering the budget constraint the solicitor faces (Gray, Fenn and Rickman, 1996a). ${ }^{11}$ Start with fee-for-service remuneration. Assume that solicitors derive utility from con-

\footnotetext{
${ }^{11} \mathrm{We}$ focus on inputs but, in principle, it is possible that solicitors could respond to standard fees by changing case volumes - independent of any possible "case-splitting", as discussed in the Introduction. Our data do not permit analysis of this because we do not have information on overall case volumes, or firm identifiers that could help establish whether 'larger'/'smaller' firms took up cases under standard fees. We consider the effects of this on our results in Footnote 24.
} 
sumption $(C)$ and leisure $(L), U(C, L), U_{i}>0, U_{i i}<0, i=C, L$. Further, assume for simplicity that the solicitor works on only one, legally aided, case where each input is remunerated at a constant rate $w$. Then, with a time constraint of $T$ and defining $H \equiv T-L$, the solicitor's problem is

$$
\max _{H} U(C, L) \quad \text { s.t. } \quad\left\{\begin{array}{l}
C=w H \\
T \geq H+L
\end{array}\right.
$$

The familiar solution $\left(U_{L} / U_{C}=w\right)$ is depicted at point $X$ in Figure 2: the solicitor is on the budget constraint $T E$, deriving utility $U_{0}$.

\section{$* * * * *$ Figure 1 here $* * * * *$}

Now consider a simplified version of the standard fee (in particular, assume only one standard fee level and ignore non-core costs, for the moment). ${ }^{12}$ As we have seen, there is an input level, say $H_{0}$, above which the solicitor is remunerated at the fee-for-service rate, $w$. Below this, however, he receives a fixed fee, $F$, regardless of his inputs. This places two "kinks" in the solicitor's budget constraint, which is now TYGZE. The problem becomes

$$
\max _{H} U(C, L) \quad \text { s.t. } \quad\left\{\begin{array}{l}
C=F \text { if } H \leq H_{0} \\
C=w H \text { if } H \geq H_{0} \\
T \geq H+L
\end{array}\right.
$$

There are now two potential outcomes. It is possible that the solicitor will choose to minimise his inputs (point $Y$ in Figure 1) or raise them in order to qualify for higher fee-for-service remuneration (point $Z$ ). We refer to these respectively as a fixed price effect and a threshold effect. Which is the outcome

\footnotetext{
${ }^{12}$ The analysis is easily generalised to more than one standard fee level.
} 
will depend on the levels of $F, w$ and $H_{0}$, the solicitor's preferences for consumption and leisure and the case's requirements (since it is easier to raise, undetected, the input level on cases which already require high input). ${ }^{13}$

Core costs form only a part of the standard fee regime: we have seen that travel and waiting time continue to be remunerated on a fee-for-service basis. The above theory is easily adapted to accommodate this possibility. As a result, we would predict that, in cases where core inputs fall, lawyers may seek to maintain income by increasing their supply of non-core inputs. This we refer to as a switching effect. ${ }^{14}$

To summarise our discussion, other things equal, we would expect to see reductions in the reported supply of those inputs covered by the standard fee, although it is possible that, at the thresholds, some cases may experience increases (to push them to a higher fee). These anticipated effects may not, however, be observed in non-core inputs; indeed, we might expect to observe substitution towards these inputs. We now describe our data before proceeding to test for the effects above.

\section{Data}

Following an original survey of legal aid bills from 1988-1990 (Gray and Fenn, 1991), the Legal Aid Board continued to collect comparable data on

\footnotetext{
${ }^{13}$ On introducing standard fees, the Lord Chancellor's expectation was that the vast majority of cases $(90 \%)$ would be captured by the two standard fee bands. Accordingly, input reductions seem likely, in practice, to outweigh input increases.

14 The extent of this latter effect captures multitask sensitivity to financial incentives. It is interesting to speculate on whether such differentiated payment is optimal in the current context. Holmström and Milgrom (1991) show that piece rates are more likely to be optimal when it is desirable to encourage the inputs in question but they are relatively unobservable, while others can be partially monitored. Although these conditions hold for some of our inputs, it is not obvious that the chosen combination of fixed and piece rates is optimal. For example, why do travel and waiting need more encouragement than, say, preparation?
} 
the inputs recorded on subsequent bills up to the end of 1994. Our dataset, therefore pools these two sources of data to provide 10,932 legal aid bills (with information on inputs reported in each case) dating from 1988 to $1994 .^{15}$ Table 3 shows the number of bills in our pooled dataset by year, with a breakdown of these into bills assessed through the original fee-for-service system, and those assessed under the new standard fee procedures. ${ }^{16}$ The new procedures were introduced in June 1993 and there was subsequently a gradual transfer of all bills received such that by January 1994 virtually all bills were assessed under standard fee procedures. Table 3 also reports the mean solicitors' costs (and their standard deviation, SD) by type of fee, to give a clear indication of the scale of work covered by standard fees in terms of payments.

\section{$* * * *$ Table 3 here ${ }^{* * * * *}$}

A set of summary descriptive statistics for the pooled dataset is contained in Table 4. Clearly, the range of costs and inputs reported by comparison with their mean values indicate a highly skewed distribution for all variables. While the mean amount claimed on bills over the whole sample period is $£ 378$, indicating the presence of a large number of bills for relatively minor offences with little representation required, there is a long upper tail of claim values, up to a maximum in the sample of nearly $£ 33,000$ for one case. This pattern is also reflected in the inputs reported in the bills: the mean numbers of attendances and hearings are just 3 and 4 respectively, but some claims report far more than this. Similarly, most cases involve little more than two

\footnotetext{
${ }^{15}$ Although the notion of core and non-core costs is specific to standard fees, our data include details on comparable inputs spanning this period.

${ }^{16}$ Note that bills assessed under the standard fee procedures may not require a standard fee if the costs exceed the upper limit proscribed for the relevant category of claim.
} 
hours time input to any of the categories reported, and little more than 6 or 7 letters and phone calls, but a minority of claims report several hundreds.

$* * * *$ Table 4 here $* * * * *$

\section{Analysis}

\subsection{Case costs}

Useful initial information can be gained by comparing the distribution of core costs for a sample of similar bills before and after the introduction of the new procedures. To do this we selected a subsample of bills received outside London in 1993 and 1994 where the case was contested (i.e. a Category 2 claim under standard fee rules). For each bill in this subsample (337 cases assessed using fee-for-service, 383 assessed under the new standard fee rules) an estimate was made of what the total core cost figure would have been if it had been costed in accordance with the rates shown in Table 2 . The distributions of the resulting cost estimates are shown for the two types of fee assessment in Figure 2.

\section{***Figure 2 here ${ }^{* * *}$}

The mean of the standard fee distribution is significantly lower than the fee-for-service distribution (£237 as opposed to £290) and this is clearly evident in the increased preponderance of lower costs in the former distribution. Moreover, although visual inspection of Figure 2 could help identify the presence of 'threshold effects', as described in Section 3, the evidence is not conclusive. ${ }^{17}$ In the remainder of this paper we focus on 'fixed-price

\footnotetext{
${ }^{17}$ It would be necessary to have more detailed information on cases around the standard fee thresholds in order to be more conclusive about the presence of this effect. Nevertheless,
} 
effects' (and 'switching effects') which may be the explanation for the general downward shift in the core cost distribution seen in Figure 2.

\subsection{Behaviour of core and non-core inputs}

We next consider graphically the behaviour of individual inputs over our data period. Figure 3 shows for each year the mean number of dates in attendance at court for each case, and the number of hearings per case. The Figure shows how, in 1993/4, reductions in the average number of attendances and hearings reported on any one bill occurred. This may be evidence to confirm the view that "case-splitting" -the submission of more than one bill per case - was occurring as a consequence of the new rules introduced in 1993.

\section{$* * * * *$ Figure 3 here $* * * * *$}

Of course, while the number of attendances and hearings per case fell, it need not be true that the number of hours worked on behalf of the client has also fallen, given that more time may have been spent on each attendance and hearing. Figures 4-6 illustrate the trends in reported time spent on various activities as declared on legal aid bills: Figures 4 and 5 relate to the items comprising core costs, while Figure 6 looks at the non-core inputs.

\section{$* * * * *$ Figures 4-6 here H**** $^{*}$}

For each of the core cost inputs, there appears to be a reduction in the number of hours or items recorded in 1994. This is most evident in the case of attendance time, and routine letters and calls. Turning to the non-core

non-parametric tests show that the two distributions in Figure 2 are dissimilar in shape: a standard Kolmogorov-Smirnov test for equality of distribution functions rejected the null of similarity with $p=0.018$; similarly, a Pearson test (see Stoline and Ury, 1979; Anderson, 1996) rejected the same null with a test statistic of 5.36 against a critical value of 3.29. 
inputs (Figure 6), the same pattern is not evident here; indeed, reported waiting time increased in 1994.

\subsection{Regression analysis of the impact of standard fees on case inputs}

We now seek clearer evidence on 'fixed price' and 'switching' effects consequent upon the introduction of standard fees. The first of these effects suggests a reduction in 'core' inputs per case over and above any reduction due to case-splitting. The second suggests an increase in non-core inputs associated with each court attendance or hearing ${ }^{18}$. These hypotheses imply testing for a change in the mean number of input hours per case, controlling for the number of attendances or hearings recorded for that case: i.e. we use a regression-based approach in which it is also possible to control for variations in inputs due to case type and location.

The estimating equation for the $j^{t h}$ input on the $i^{\text {th }}$ case is therefore

$$
H_{i j}=\alpha_{j}+\beta_{j} C_{i j}+\gamma_{j} \mathbf{X}_{i j}+\delta_{j} D_{j}+v_{i j}
$$

where $H_{i j}$ represents the total number of inputs declared in the $i^{\text {th }}$ bill, $C_{i j}$ is the number of dates (attendances or hearings) on which the inputs were provided, $\mathbf{X}_{i j}$ is a vector of other factors which affect the complexity of the case (described below), and $D_{j}$ represents a dummy variable taking the value 1 if the bill was assessed under standard fee rules, and zero otherwise ${ }^{19}$.

\footnotetext{
${ }^{18}$ For most inputs, the natural driver to consider is the number of court attendances; however, for advocacy time, it is more appropriate to use the number of hearings.

${ }^{19}$ The intervention variable $D_{j}$ is defined in terms of the assessment procedure used for each claim. It is not an indicator variable for whether a standard fee was in fact applied to the bill, as this would clearly be endogenous.
} 
The parameters to be estimated are $\alpha_{j}, \beta_{j}, \gamma_{j}, \delta_{j}$, and $v_{i j}$ is the residual. In particular, we are looking to test the null hypothesis for each input that $\delta_{j}=$ 0 : that is, that there was no structural break attributable to the introduction of standard fee assessment procedures.

While it is feasible to estimate consistently the system in (1) as a set of ordinary least squares regressions, it seems quite likely that the error terms $v_{i j}$ are correlated across inputs $\left(E\left(v_{i j} v_{i k}\right)=\sigma_{j k}\right)$. That is, if a solicitor chooses to spend relatively more time on preparation for a particular case, it is likely that she will also choose to spend relatively more time on other core inputs such as letter writing, and possibly less time on non-core inputs such as travel and waiting. When estimating the system of equations in (1), it consequently makes sense to take this information into account in order to improve the efficiency of the estimates. Therefore we estimate the parameters in (1) using Zellner's seemingly unrelated regression estimator (SURE) - an asymptotically efficient generalised least squares algorithm. The inputs for which we have information are: attendance hours; advocacy hours; preparation hours; waiting hours; travelling hours; letters written; and telephone calls made.

Thus, we estimate using SURE a system of seven equations in which the independent variables include a relevant measure of the number of attendances or hearings; the number of defendants in the case; the plea (where relevant); and dummy variables representing the offence type, the legal aid region, and the intervention variable indicating whether the bill was assessed under standard fee rules. The estimation results and diagnostics are reported in Table 5, and the associated correlation matrix of residuals is shown in Table 5a. The latter table is provided to demonstrate that, as expected, the unexplained variations in inputs are generally positively correlated with each other-for example, a case in which an unusually high number of letters 
is written is likely also to have an unusually high number of phone calls $(r=0.4399)^{20}$ It is this inter-equation correlation which provides the additional efficiency for the SURE estimator.

\section{$* * * * *$ Tables 5 and 5 a here ${ }^{* * * * *}$}

The estimation results in Table 5 suggest that increasing the number of defendants has a positive effect on all the inputs (and is statistically significant in all cases apart from waiting time). ${ }^{21}$ Also the presence of a not guilty plea significantly increases all relevant inputs as might be expected. These results are intuitive in so far as more defendants and contested prosecutions increase case complexity. As also expected, the number of dates spent in attendance or at hearings increase each input level significantly. Finally there are plausible and significant relationships between inputs used and offence types as well as court locations. ${ }^{22}$

The coefficient estimates for the standard fee regressor imply that the impact of the new rules resulted in a significant reduction in the amount of attendance, preparation and advocacy time spent per attendance, and in the number of letters and telephone calls per attendance. By contrast, waiting time per attendance increased significantly and travel time per attendance remained constant. ${ }^{23}$ It is therefore apparent that the items covered by the

\footnotetext{
${ }^{20}$ The Breusch-Pagan test of independence at the foot of the table is highly significant, indicating that the null of significant correlation between equations cannot be rejected.

${ }^{21}$ To illustrate with an example, an extra defendant increases the expected attendance time by $0.299 \times 60 \approx 18$ minutes, while it adds 0.443 to the expected number of routine telephone calls and 1.96 to the expected number of letters.

${ }^{22}$ Note that the omitted offence category was 'Other'. The estimated coefficients on the regional dummy variables are not reported for clarity (there were some significant differences across regions: in particular the levels of most inputs were higher in London and the South East than elsewhere).

${ }^{23}$ Following our discussion in Footnote 14, it is interesting to speculate on whether the difference between our travel and waiting time results is related to monitoring costs. Arguably, it may be easier for an assessor to estimate typical travel time than to be aware of time spent waiting on a case.
} 
standard fee generally fell, whereas those continuing to be reimbursed on an itemised basis either rose or remained unchanged.

\section{$* * * * *$ Table 6 here $* * * * *$}

These results broadly confirm the hypothesis that solicitors reacted to the withdrawal of a fee for service arrangement on some inputs by, on average, reducing the supply of these inputs, whereas for those inputs which continued to be reimbursed retrospectively solicitors either did not significantly change their supply (travel time) or substituted more of the input for others that had been reduced (waiting time). ${ }^{24}$

\section{Conclusions}

The introduction of standard fees for criminal cases in Magistrates' Courts in 1993 provides a 'natural experiment' for examining the effects of prospective fixed price contracts in comparison with retrospective fee-for-service contracts. This is valuable in the context of contract theory because the opportunity to test predictions from a body of theory seldom arises given available data (particularly outside the health care setting). It is valuable in the context of policy when the authorities in England and Wales and Scotland have placed (and continue to place) notable reliance on prospectively set fees in order to achieve a variety of objectives; from (legal aid) expenditure control

\footnotetext{
${ }^{24}$ Section 3 noted that firms could also respond to standard fees by changing the volume of cases they took. In particular, it might be suggested that firms would take more cases in order to generate efficiencies and gain rents. Such an effect seems unlikely to account for our results. First, if changes did occur, firms are likely to have taken longer than a year to adjust their business profiles (this may have required hiring or re-skilling); thus, our post-1993 data are unlikely to reflect this. Second, and perhaps more importantly, if the input reductions we observe are due to increased efficiency, it is unclear why they did not impact on travel and waiting time. Thus, the pattern of responses that we observe seem more consistent with the behaviour we have described.
} 
to access to justice. Our results, suggesting that solicitors appear generally to have responded to standard fees in the way that contract theory would predict, therefore have wide implications.

We have found that, when presented with remuneration that did not reward the application of extra inputs (other than at higher thresholds), solicitors reduced their supply of such inputs in comparison with previous practice. In contrast, where fee-for-service continued to be in place, solicitors raised the levels of inputs supplied, apparently substituting these for those inputs where marginal cost was not covered - in precisely the way suggested by literature on multitask agency.

Following the introduction of standard fees, the average cost of cases covered by the scheme fell (following five consecutive-on-year increases). Our results suggest that the effects, however, may have been wider than this immediate drop in the unit cost of bills in 1994. For a start, it seems to be the case that legally aided defendants (and the Legal Aid Board) received a different "product" following the introduction of standard fees in 1993. It is not possible to say which of these products was superior: this would depend on the extent to which inputs and output quality are positively related and the extent to which some of the work done prior to 1993 added value to the client's case. However, even if one simply looks at the expenditure effects of standard fees, the combination of case-splitting and increased travel and waiting implies hidden increases in, and incomplete control of, expenditure which another incentive scheme might have avoided. Of course, it should also be appreciated that an important objective of standard fees (and legal aid reform more generally) was to control the potential for supplier-induced expenditure increases as observed in US health care (see Bevan, Holland and Partington, 1994); as such, our results may indicate merit in the reforms. 
More generally, our paper complements Gray, Rickman and Fenn (1999) and suggests that solicitors do respond to financial incentives; something that economic theory recognises, and current/future reform should acknowledge.

\section{References}

Anderson, G. (1996): "Nonparametric tests of stochastic dominance in income distributions", Econometrica, 64, 1183-1193

Arrow, K. (1963): "Uncertainty and the welfare economics of medical care", American Economic Review, 53, 941-973.

Baker, G. (1992): "Incentive contracts and performance measurement", Journal of Political Economy, 100, 598-614.

Bevan G. (1996): "Has there been supplier-induced demand for legal aid?", Civil Justice Quarterly, 15, 98-114.

Bevan G. (1998): "Quasi-markets for legal aid", in W. Bartlett, J. Roberts\& J. Le Grand (eds), A Revolution in Social Policy: Lessons from Developments in Quasi-markets, Policy Press: Bristol.

Bevan, G., T. Holland \& M. Partington (1994): "Organising cost-effective access to justice." Memorandum no. 9, Social Market Foundation: London.

Bickerdyke, I., Dolamore. R., Monday, I. \& R. Preston (2002): SupplierInduced Demand for Medical Services, Productivity Commission Staff Working Paper, Canberra, Australia. 
Cape, E. \& R. Moorhead (2005): "Demand induced supply? Identifying cost drivers in criminal defence work: A report to the Legal Services Commission, forthcoming.

DCA (2003): "New scheme for road traffic accident claims heralds revolution in legal costs", Department of Constitutional Affairs, Press Release 377/03, 6 October.

Dismuke, C \& V. Sena (1999): "Has DRG payment influenced the technical efficiency and productivity of diagnostic technologies in Portuguese public hospitals? An empirical analysis using parametric and nonparametric methods", Health Care Management Science, 2(2), 107-116.

Edwards, A. (1993): Standard Fees in the Magistrates' Courts: A Survival Guide, The Law Society: London.

Folland, S., Goodman, A. \& M. Stano (2001): The Economics of Health and Health Care, 3rd edition, Prentice Hall: Upper Saddle River, NJ.

Gay, E. \& J. Kronenfeld (1990): "Regulation, retrenchment- the DRG experience: Problems from changing reimbursement practice", Social Science and Medicine, 31, 1103-1118.

Gibbons, R. \& K. Murphy (1992); "Optimal incentive contracts in the presence of career concerns", Journal of Political Economy, 100, 468-506.

Gilman, B. (2000): "Hospital response to DRG refinements: The impact of multiple reimbursement incentives on inpatient length of stay", Health Economics, 9(4), 277-294.

Gray, A. (1994): "The reform of legal aid", Oxford Review of Economic Policy, 10(1), 51-67. 
Gray, A. \& P. Fenn (1991): "The rising cost of legally aided criminal cases", New Law Journal, November 29, 1622-1631.

Gray, A., Fenn, P. \& N. Rickman (1996a): "Controlling lawyer's costs through standard fees: An economic analysis", in R. Young \& D. Wall (eds.), Access to Criminal Justice: Legal Aid, Lawyers and the Defence of Liberty, Blackstone Press: London.

Gray, A., Fenn, P. \& N. Rickman (1996b): "Monitoring legal aid: Back to first principals", in F. Stephen (ed.), Access to Justice, Hume Paper on Public Policy, 4(4), 24-35.

Gray, A., Rickman, N. \& P. Fenn (1999): "Professional autonomy and the cost of legal aid", Oxford Economic Papers, 51, 544-558.

Holmström, B. \& P. Milgrom (1991): "Multitask principal-agent analyses: Incentive contracts, asset ownership and job design", Journal of Law, Economics and Organisation, 7 (special issue), 24-52.

Krasnik, A., Groenewegen, P., Pedersen, P., Scholten, P., Mooney, G., Gottschau, A., Flierman, H. \& M. Damsgaard (1990): "Changing remuneration systems: effects on activity in general practice", British Medical Journal, 300, 1698-1701.

Kroneman. M \& J. Nagy (2001): "Introducing DRG-based financing in Hungary: A study into the relationship between supply of hospital beds and use of these beds under changing institutional circumstances", Health Policy, 55, 19-36.

Labelle, R., Stoddart, G. \& T. Rice (1994a): "A re-examination of the meaning and importance of supplier-induced demand", Journal of Health Economics, 13(2), 347-368. 
Labelle, R., Stoddart, G. \& T. Rice (1994b): "Response to Pauly on a re-examination of the meaning and importance of supplier-induced demand", Journal of Health Economics, 13(4), 491-494.

Laffont, J-J \& J. Tirole (1993): A Theory of Incentives and Procurement in Regulation, MIT Press: Cambridge, Mass.

Lazear, E. (1996): "Performance pay and productivity", NBER Working Paper 5672 .

Legal Aid Board (1994): Annual Report, 1993-94, HMSO: London.

Lord Chancellor's Department (1996): Striking the Balance: The Future of Legal Aid in England and Wales, Cm 3305, HMSO: London.

Lord Chancellor's Department (1998): Modernising Justice, Cm 4155, HMSO: London.

McClellan, M. (1997): "Hospital reimbursement incentives: An empirical analysis", Journal of Economics $\mathscr{G}$ Management Strategy, 6(1), 91-128.

Olson, M. (1996): "Substitution in regulatory agencies: FDA enforcement alternatives", Journal of Law, Economics and Organisation 12(2), 376407.

Paarsch, H. \& B. Shearer (1996): "Fixed wages, piece rates, and incentive effects", mimeo: University of Laval.

Pauly, M. (1994a): "Editorial: A re-examination of the meaning and importance of supplier-induced demand", Journal of Health Economics, 13(3), 369-372. 
Pauly, M. (1994b): "Reply to Roberta Labelle, Greg Stoddart and Thomas Rice", Journal of Health Economics 13(4), 495-496.

Phelps, C. (1986): "Induced demand. Can we ever know its extent?", Journal of Health Economics, 5, 355-364.

Prendergast, C. (1999): "The provision of incentives in firms", Journal of Economic Literature, 37(1), 7-63.

Rice, T. (1983): "The impact of changing Medicare reimbursement rates on physician-induced demand", Medical Care, 21, 803-815.

Schramm, C. \& J. Gabel (1988): "Prospective payment. Some retrospective observations", New England Journal of Medicine, 318, 1681-1683.

Slade, M. (1996): "Multitask agency and organisational form: An empirical exploration", International Economic Review, 37, 465-486.

Stoline, M. \& H. Ury (1979): "Tables of the Studentised Maximum Modulus Distribution and an application to multiple comparisons among means", Technometrica, 21, 87-93.

Woolf, Lord H. (1996): "Access to justice: A report to the Lord Chancellor on the civil justice system in England and Wales", Lord Chancellor's Department, London.

Yip, W. (1998): "Physician responses to medical fee reductions: Changes in the volume and intensity of Coronary Artery Bypass Graft (CABG) surgeries in the medicare and private sectors", Journal of Health Economics, 17(6), 675-700.

Zander, M. (1993): Cases and Materials on the English Legal System, 6th edition, Butterworths: London. 
Table 1: Standard fees 1993/4 (non-London)

\begin{tabular}{|c|c|c|c|c|}
\hline $\begin{array}{l}\text { Types of } \\
\text { proceedings }\end{array}$ & Lower st'd. fee & Lower limit & Higher st'd. fee & Higher limit \\
\hline Category 1 & $£ 140$ & $£^{261}$ & $£ 336$ & $f^{451}$ \\
\hline Category 2 & $£ 247$ & $£ 447$ & $£, 566$ & $£ 745$ \\
\hline Category 3 & $£ 223$ & $£ 395$ & $£, 505$ & $f_{689}$ \\
\hline
\end{tabular}

Table 2: Itemised rates, 1993/4 (non-London)

\begin{tabular}{ll}
\hline Class of work & Rate \\
Preparation & $£ 43.25$ per hour \\
Advocacy & $£ 54.50$ per hour \\
Attendance at court & $£ 29.50$ per hour \\
Travel and waiting & $£ 24.25$ per hour \\
Routine letters/telephone calls & $£ 3.35$ per item. \\
\hline
\end{tabular}

Table 3: Numbers of bills by year and type of fee, 1988-94, and mean (and SD) solicitors' costs $(f)$ by type of fee, 1993-94

\begin{tabular}{|c|c|c|c|c|c|}
\hline \multirow[b]{2}{*}{ Year } & \multirow[t]{2}{*}{ FFS } & \multicolumn{3}{|c|}{ Std fee (category) } & \multirow[t]{2}{*}{ Total } \\
\hline & & 1 & 2 & 3 & \\
\hline 1988 & 759 & & & & 759 \\
\hline 1989 & 1059 & & & & 1059 \\
\hline 1990 & 1270 & & & & 1270 \\
\hline 1991 & 2215 & & & & 2215 \\
\hline 1992 & 2132 & & & & 2132 \\
\hline 1993 & 1440 & 316 & 100 & 83 & 1939 \\
\hline 1994 & 72 & 842 & 351 & 293 & 1558 \\
\hline Total & 8947 & 1158 & 451 & 376 & 10932 \\
\hline \multirow[t]{2}{*}{ Mean (SD) solicitors' costs 1993-94 } & $£, 536$ & $£^{239}$ & $£^{4} 20$ & $£ 423$ & $£^{411}$ \\
\hline & $(£, 1172)$ & $(£ 135)$ & $(£ 230)$ & $(£, 362)$ & $(£ 731)$ \\
\hline
\end{tabular}


Table 4: Descriptive statistics, 1988-1994

\begin{tabular}{lrrrrr}
\hline & N & Min. & Max. & Mean & $\begin{array}{r}\text { St'd. } \\
\text { deviation }\end{array}$ \\
Total Solicitors Costs (Inc VAT) & 10932 & 4 & 32884 & 378 & 659 \\
No. of Dates in Attendance & 10561 & 0 & 67 & 4 & 3 \\
No. of Dates in Advocacy & 10420 & 0 & 32 & 3 & 2 \\
Time attending (hrs) & 10827 & 0 & 77 & 2 & 2 \\
Time in Advocacy (hrs) & 10817 & 0 & 69 & 1 & 2 \\
Time Preparing (hrs) & 10824 & 0 & 234 & 2 & 4 \\
Travelling time (hrs) & 10813 & 0 & 100 & 1 & 2 \\
Waiting time (hrs) & 10814 & 0 & 69 & 1 & 2 \\
No. of Letters Written & 10821 & 0 & 120 & 7 & 8 \\
No. of Telephone Calls & 10819 & 0 & 234 & 6 & 9 \\
\hline
\end{tabular}


Table 5: SURE regression results

\begin{tabular}{|c|c|c|c|c|c|c|c|}
\hline & (1) & (2) & (3) & (4) & (5) & $(6)$ & (7) \\
\hline & $\begin{array}{c}\text { Time } \\
\text { attending }\end{array}$ & $\begin{array}{l}\text { Time in } \\
\text { advocacy }\end{array}$ & $\begin{array}{c}\text { Time } \\
\text { preparing }\end{array}$ & $\begin{array}{l}\text { Letters } \\
\text { written }\end{array}$ & $\begin{array}{c}\text { Phone } \\
\text { calls made }\end{array}$ & $\begin{array}{l}\text { Travelling } \\
\text { time }\end{array}$ & $\begin{array}{c}\text { Time } \\
\text { waiting }\end{array}$ \\
\hline No of defendants & $\begin{array}{c}0.299 \\
(8.01)^{* *}\end{array}$ & $\begin{array}{c}0.203 \\
(5.46)^{* *}\end{array}$ & $\begin{array}{c}0.238 \\
(2.61)^{* *}\end{array}$ & $\begin{array}{c}1.963 \\
(13.10)^{* *}\end{array}$ & $\begin{array}{c}0.443 \\
(2.41)^{*}\end{array}$ & $\begin{array}{c}0.150 \\
(3.11)^{* *}\end{array}$ & $\begin{array}{l}0.012 \\
(0.34)\end{array}$ \\
\hline Not guilty plea & $\begin{array}{c}0.128 \\
(3.80)^{* *}\end{array}$ & $\begin{array}{c}0.250 \\
(7.05)^{* *}\end{array}$ & $\begin{array}{c}0.309 \\
(3.56)^{* *}\end{array}$ & $\begin{array}{c}1.670 \\
(11.13)^{* *}\end{array}$ & $\begin{array}{c}0.461 \\
(2.67)^{* *}\end{array}$ & & \\
\hline Dates in attendance & $\begin{array}{c}0.470 \\
(96.23)^{* *}\end{array}$ & & $\begin{array}{c}0.320 \\
(26.14)^{* *}\end{array}$ & $\begin{array}{c}1.144 \\
(55.45)^{* *}\end{array}$ & $\begin{array}{c}1.095 \\
(43.75)^{* *}\end{array}$ & $\begin{array}{c}0.216 \\
(33.68)^{* *}\end{array}$ & $\begin{array}{c}0.182 \\
(35.82)^{* *}\end{array}$ \\
\hline Dates in advocacy & & $\begin{array}{c}0.376 \\
(58.78)^{* *}\end{array}$ & & & & & \\
\hline Violence & $\begin{array}{l}-0.075 \\
(1.26)\end{array}$ & $\begin{array}{c}-0.223 \\
(3.76)^{* *}\end{array}$ & $\begin{array}{l}-0.154 \\
(1.06)\end{array}$ & $\begin{array}{c}1.151 \\
(4.85)^{* *}\end{array}$ & $\begin{array}{c}-0.249 \\
(0.86)\end{array}$ & $\begin{array}{l}-0.152 \\
(2.00)^{*}\end{array}$ & $\begin{array}{l}0.048 \\
(0.83)\end{array}$ \\
\hline Robbery & $\begin{array}{l}0.100 \\
(0.73)\end{array}$ & $\begin{array}{l}-0.150 \\
(1.09)\end{array}$ & $\begin{array}{l}0.206 \\
(0.62)\end{array}$ & $\begin{array}{c}-0.288 \\
(0.53)\end{array}$ & $\begin{array}{l}1.248 \\
(1.86)\end{array}$ & $\begin{array}{l}0.342 \\
(1.94)\end{array}$ & $\begin{array}{c}0.534 \\
(3.95)^{* *}\end{array}$ \\
\hline Sexual Offences & $\begin{array}{c}0.360 \\
(2.74)^{* *}\end{array}$ & $\begin{array}{c}-0.414 \\
(3.16)^{* *}\end{array}$ & $\begin{array}{l}-0.172 \\
(0.54)\end{array}$ & $\begin{array}{l}0.786 \\
(1.50)\end{array}$ & $\begin{array}{l}1.638 \\
(2.54)^{*}\end{array}$ & $\begin{array}{l}0.059 \\
(0.35)\end{array}$ & $\begin{array}{c}-0.045 \\
(0.35)\end{array}$ \\
\hline Burglary & $\begin{array}{c}-0.316 \\
(4.93)^{* *}\end{array}$ & $\begin{array}{c}-0.453 \\
(7.06)^{* *}\end{array}$ & $\begin{array}{c}-0.122 \\
(0.78)\end{array}$ & $\begin{array}{c}0.537 \\
(2.10)^{*}\end{array}$ & $\begin{array}{c}-0.256 \\
(0.81)\end{array}$ & $\begin{array}{l}0.004 \\
(0.04)\end{array}$ & $\begin{array}{c}0.407 \\
(6.44)^{* *}\end{array}$ \\
\hline Theft & $\begin{array}{c}-0.273 \\
(5.09)^{* *}\end{array}$ & $\begin{array}{c}-0.364 \\
(6.79)^{* *}\end{array}$ & $\begin{array}{l}-0.206 \\
(1.57)\end{array}$ & $\begin{array}{c}0.728 \\
(3.39)^{* *}\end{array}$ & $\begin{array}{l}-0.382 \\
(1.45)\end{array}$ & $\begin{array}{l}-0.102 \\
(1.48)\end{array}$ & $\begin{array}{c}0.221 \\
(4.18)^{* *}\end{array}$ \\
\hline Fraud & $\begin{array}{c}0.280 \\
(2.58)^{* *}\end{array}$ & $\begin{array}{l}-0.216 \\
(1.99)^{*}\end{array}$ & $\begin{array}{c}2.495 \\
(9.42)^{* *}\end{array}$ & $\begin{array}{l}0.607 \\
(1.40)\end{array}$ & $\begin{array}{l}0.401 \\
(0.75)\end{array}$ & $\begin{array}{c}0.353 \\
(2.53)^{*}\end{array}$ & $\begin{array}{l}0.071 \\
(0.66)\end{array}$ \\
\hline Criminal Damage & $\begin{array}{c}-0.262 \\
(3.01)^{* *}\end{array}$ & $\begin{array}{l}-0.174 \\
(2.01)^{*}\end{array}$ & $\begin{array}{l}-0.210 \\
(0.99)\end{array}$ & $\begin{array}{c}0.762 \\
(2.19)^{*}\end{array}$ & $\begin{array}{l}-0.355 \\
(0.83)\end{array}$ & $\begin{array}{l}-0.247 \\
(2.20)^{*}\end{array}$ & $\begin{array}{l}0.030 \\
(0.34)\end{array}$ \\
\hline Drugs Offences & $\begin{array}{c}-0.056 \\
(0.57)\end{array}$ & $\begin{array}{c}-0.284 \\
(2.88)^{* *}\end{array}$ & $\begin{array}{c}0.532 \\
(2.20)^{*}\end{array}$ & $\begin{array}{c}0.811 \\
(2.05)^{*}\end{array}$ & $\begin{array}{l}0.618 \\
(1.27)\end{array}$ & $\begin{array}{c}0.388 \\
(3.05)^{* *}\end{array}$ & $\begin{array}{c}0.197 \\
(2.03)^{*}\end{array}$ \\
\hline Motoring Offences & $\begin{array}{c}-0.251 \\
(3.89)^{* *}\end{array}$ & $\begin{array}{c}-0.204 \\
(3.16)^{* *}\end{array}$ & $\begin{array}{l}-0.261 \\
(1.65)\end{array}$ & $\begin{array}{c}0.975 \\
(3.77)^{* *}\end{array}$ & $\begin{array}{c}-0.045 \\
(0.14)\end{array}$ & $\begin{array}{c}-0.108 \\
(1.29)\end{array}$ & $\begin{array}{c}0.136 \\
(2.13)^{*}\end{array}$ \\
\hline Standard Fee & $\begin{array}{c}-0.484 \\
(10.41)^{* *}\end{array}$ & $\begin{array}{c}-0.262 \\
(5.66) * *\end{array}$ & $\begin{array}{l}-0.285 \\
(2.51)^{*}\end{array}$ & $\begin{array}{c}-1.355 \\
(7.27)^{* *}\end{array}$ & $\begin{array}{c}-1.678 \\
(7.34)^{* *}\end{array}$ & $\begin{array}{c}-0.005 \\
(0.08)\end{array}$ & $\begin{array}{c}0.206 \\
(4.50)^{* *}\end{array}$ \\
\hline Constant & $\begin{array}{c}0.591 \\
(7.77)^{* *}\end{array}$ & $\begin{array}{c}-0.036 \\
(0.47)\end{array}$ & $\begin{array}{c}1.051 \\
(5.64)^{* *}\end{array}$ & $\begin{array}{l}-0.601 \\
(1.97)^{*}\end{array}$ & $\begin{array}{c}4.464 \\
(11.93)^{* *}\end{array}$ & $\begin{array}{c}0.845 \\
(8.68)^{* *}\end{array}$ & $\begin{array}{c}0.717 \\
(9.62)^{* *}\end{array}$ \\
\hline Observations & 9480 & 9480 & 9480 & 9480 & 9480 & 9480 & 9480 \\
\hline R-sq & 0.5332 & 0.2726 & 0.1173 & 0.3193 & 0.2254 & 0.1542 & 0.1473 \\
\hline chi 2 & 10667.98 & 3897.76 & 1057.6 & 4316.53 & 2535 & 1473.68 & 1587.98 \\
\hline $\mathrm{P}$ & 0.0000 & 0.0000 & 0.0000 & 0.0000 & 0.0000 & 0.0000 & 0.0000 \\
\hline $\begin{array}{l}\text { Absolute value of } z \\
* \text { significant at } 5 \% \text {; }\end{array}$ & $\begin{array}{l}\text { tistics in } \\
\text { ignifican }\end{array}$ & $\begin{array}{l}\text { ntheses } \\
1 \%\end{array}$ & & & & & \\
\hline
\end{tabular}


Table 5a: Correlation matrix of residuals between SURE equations

\begin{tabular}{|c|c|c|c|c|c|c|c|}
\hline $\begin{array}{l}\text { Equation: } \\
\text { (1) Time attending }\end{array}$ & $\begin{array}{l}\text { Time } \\
\text { attending } \\
1.0000\end{array}$ & $\begin{array}{l}\text { Time in } \\
\text { advocacy }\end{array}$ & $\begin{array}{l}\text { Time } \\
\text { preparing }\end{array}$ & $\begin{array}{l}\text { No of } \\
\text { letters }\end{array}$ & $\begin{array}{l}\text { No of } \\
\text { phone } \\
\text { calls }\end{array}$ & $\begin{array}{l}\text { Travelling } \\
\text { time }\end{array}$ & $\begin{array}{l}\text { Waiting } \\
\text { time }\end{array}$ \\
\hline (2) Time in advocacy & 0.4387 & 1.0000 & & & & & \\
\hline (3) Time preparing & 0.4405 & 0.3338 & 1.0000 & & & & \\
\hline (4) No of letters & 0.1600 & 0.0916 & 0.1306 & 1.0000 & & & \\
\hline (5) No of phone calls & 0.3607 & 0.2189 & 0.2398 & 0.4399 & 1.0000 & & \\
\hline (6) Travelling time & 0.4590 & 0.3548 & 0.3512 & 0.1696 & 0.3772 & 1.0000 & \\
\hline (7) Waiting time & 0.1152 & 0.0486 & 0.0709 & 0.0919 & 0.1461 & 0.2970 & 1.0000 \\
\hline Breusch-Pagan test of & independer & e: $\operatorname{chi} 2(21)$ & $=16598$. & , $\operatorname{Pr}=0$ & 000 & & \\
\hline
\end{tabular}


Figure 1: Standard fees and the solicitor's budget constraint

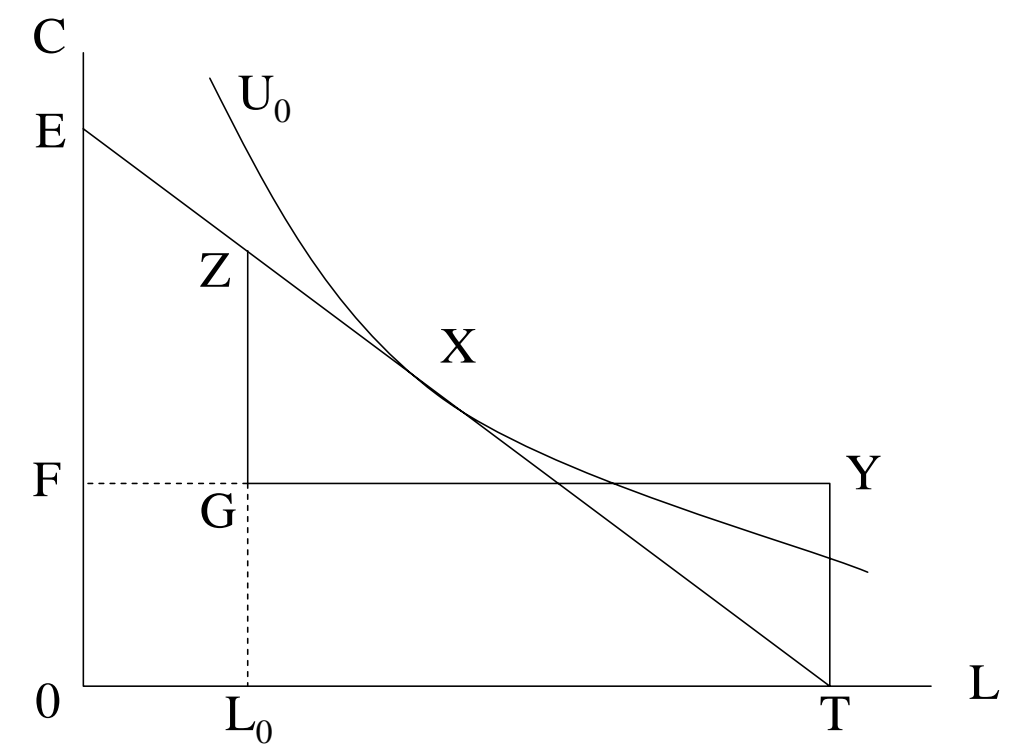

Figure 2: Distribution of core costs ( $£$ ) for category 2 type bills, non-London 1993/4

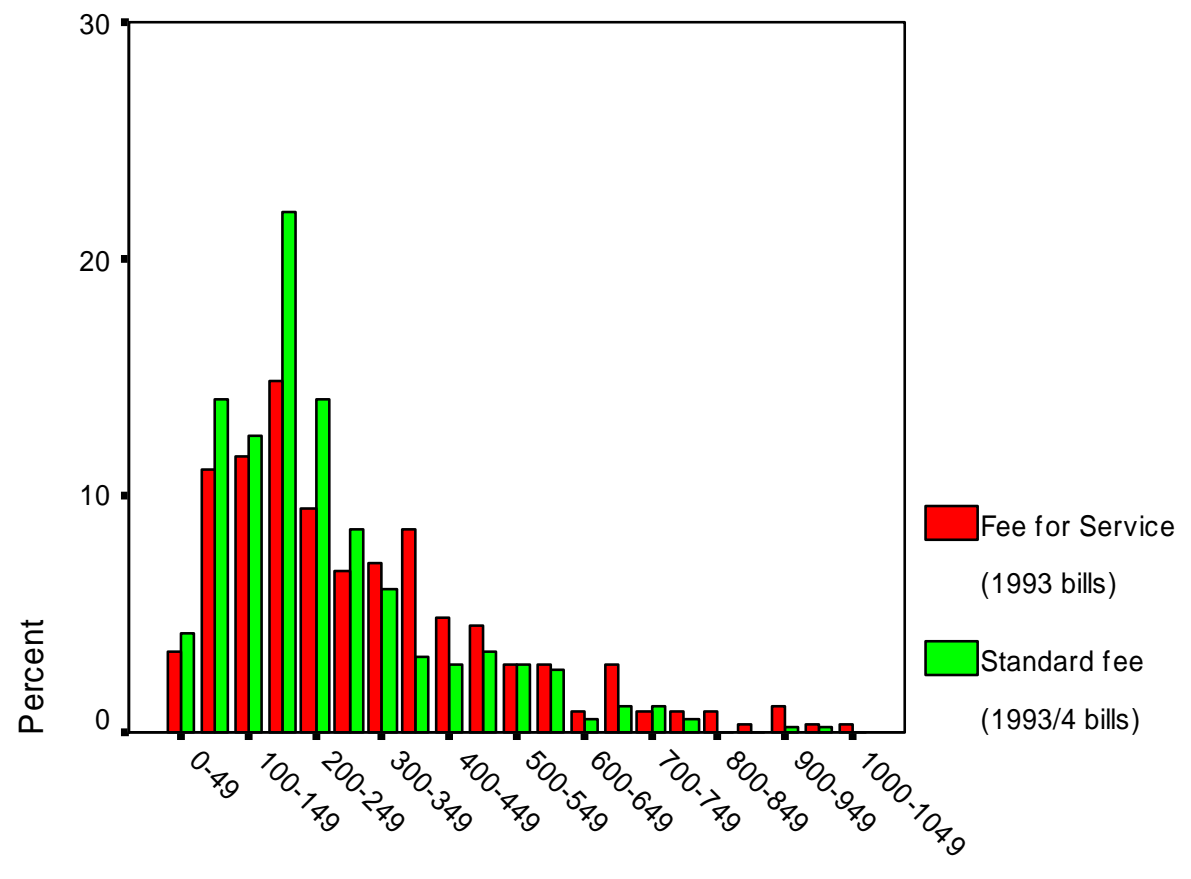

Core costs 
Figure 3: Number of attendances and hearings per case, all bills 1988-94

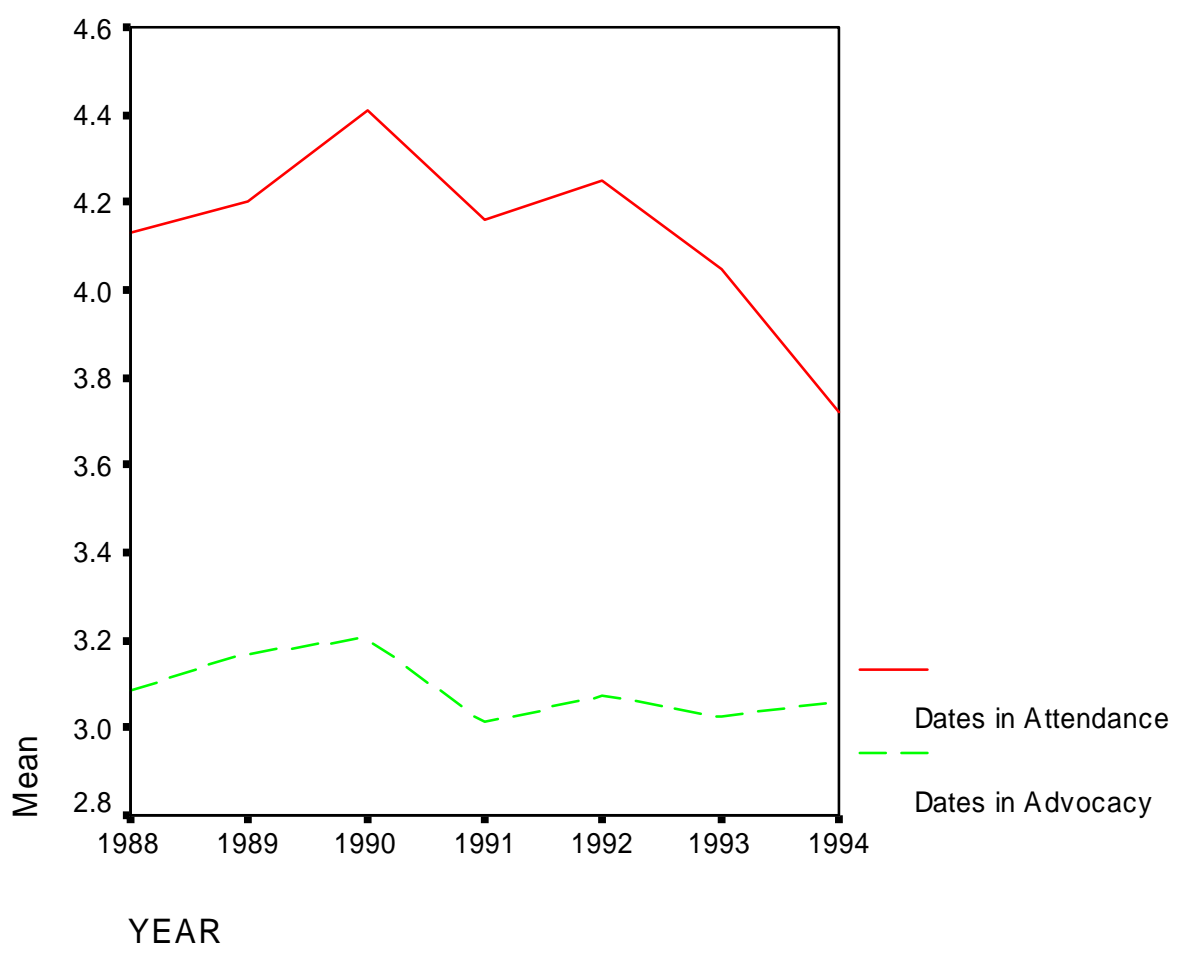

Figure 4: Mean hours per case in attendance, advocacy and preparation, all bills 198894

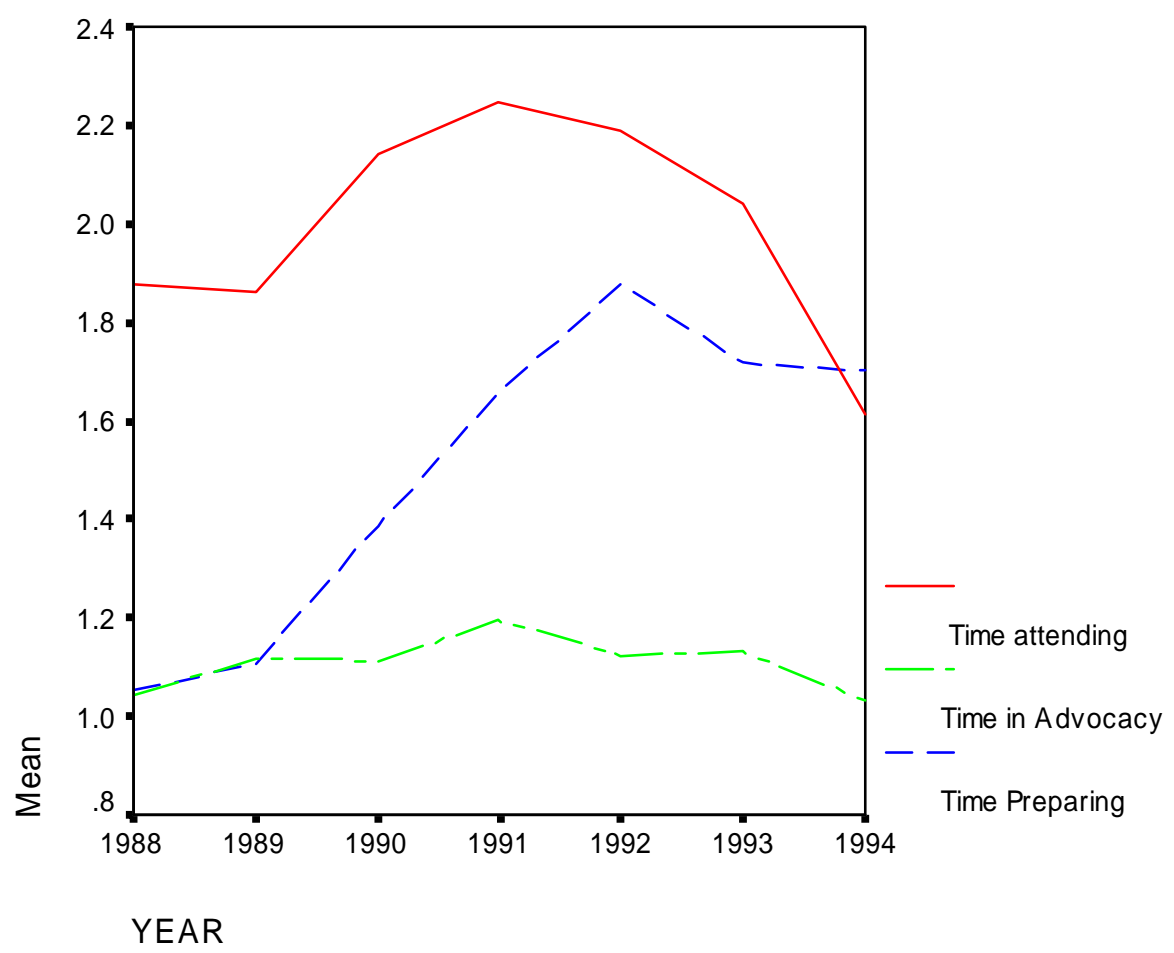


Figure 5: Mean numbers of letters and phone calls per case, all bills 1988-94

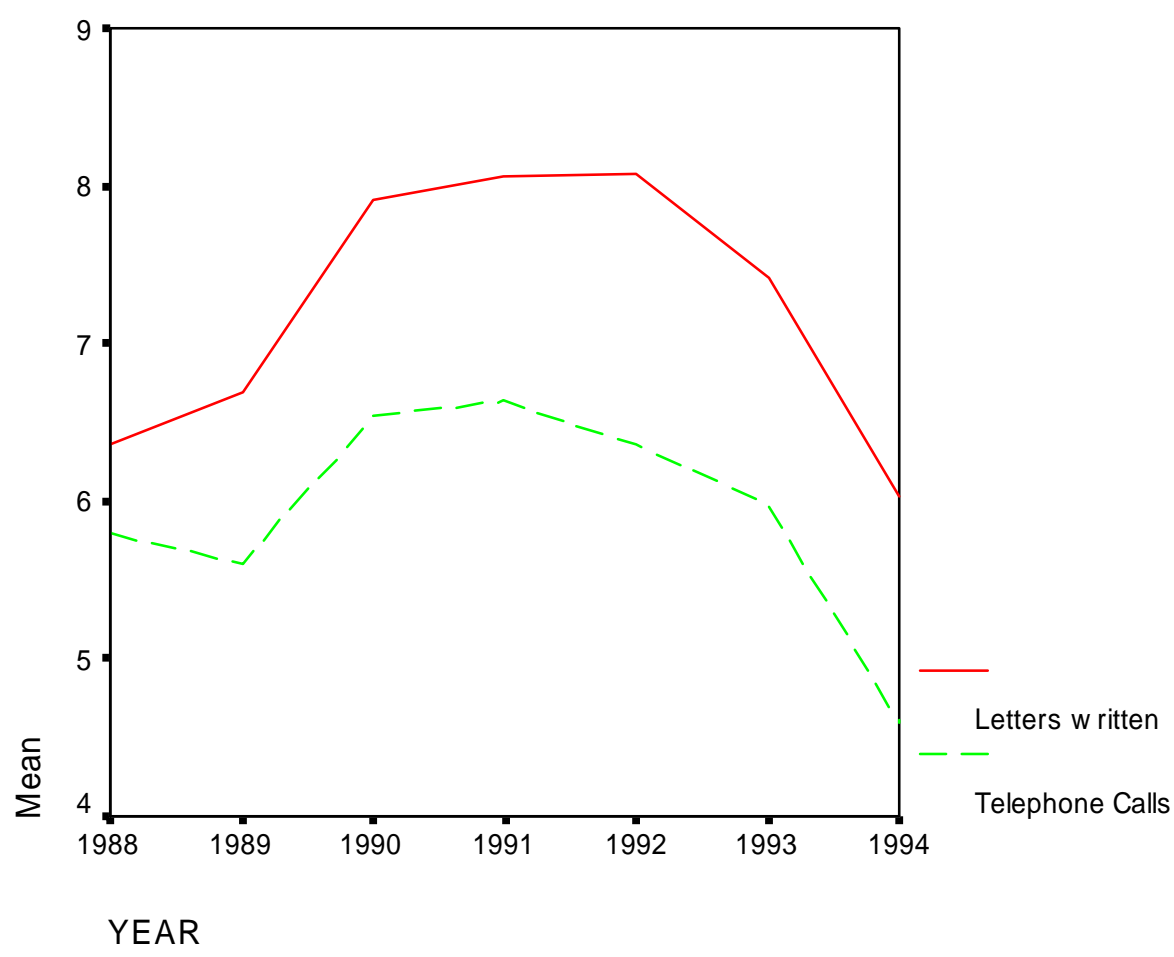

Figure 6: Mean hours per case in travelling and waiting, all bills 1988-94

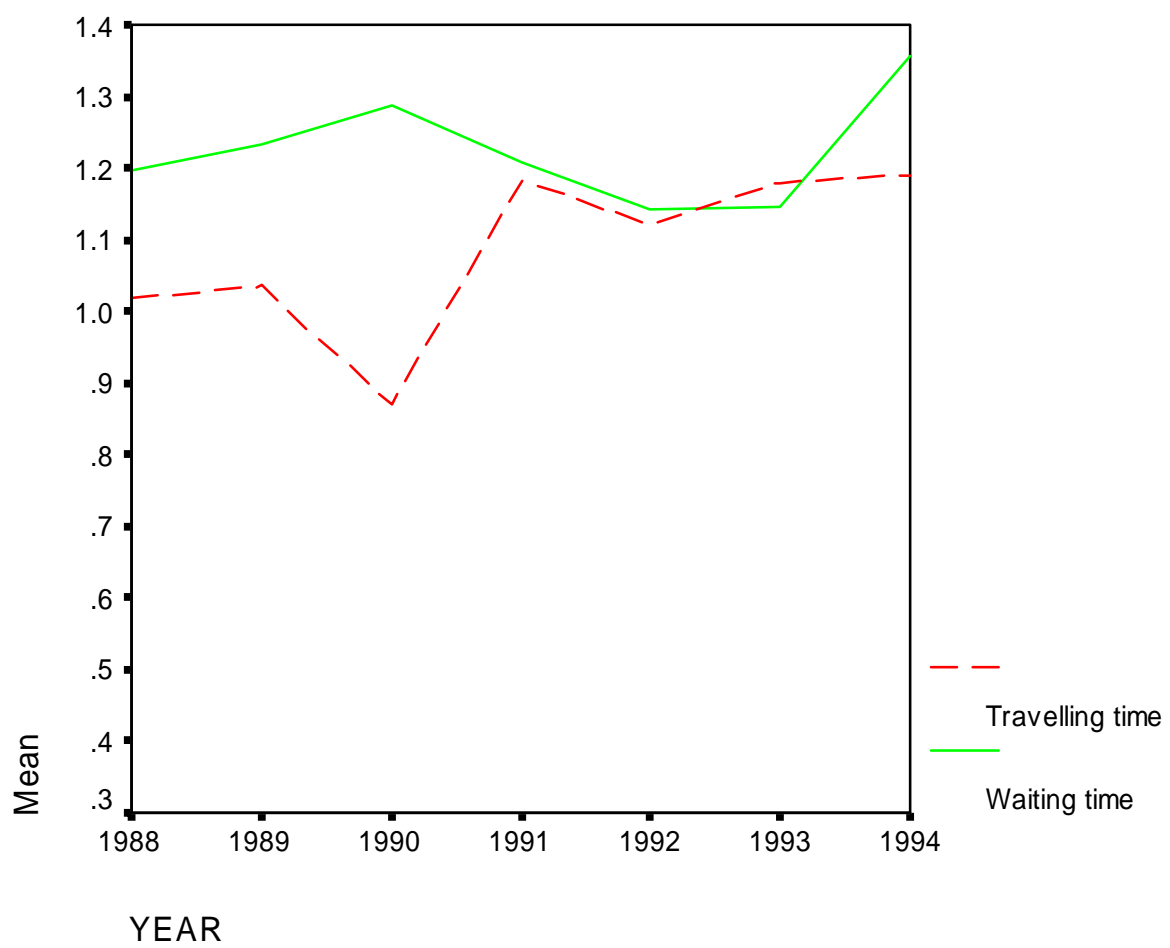

